American enthusiasm for erythromycin was not justified by the British experience. But clinically the British cases are not entirely similar to those in the United States, where patients have been predominantly immunosuppressed and have possibly acquired their infections in institutions or hospitals.

Diagnosis, Miller claimed, could be made with reasonable confidence on the basis of albuminuria, hyponatraemia, and abnormal liver function. But the Ciba meeting felt strongly that these criteria should be tested by serologically examining all patients with atypical pneumonia who had these features. Serological diagnosis is based on an antibody titre equal to or greater than 256 or a fourfold rise in antibody to specific antigen. But to which antigen? The standard Philadelphia CDC antigen gives an appreciable incidence of false-positive diagnoses, and the formolinised yolk sac antigen may give false-negative results. Moreover, in some cases where the organism has been found in lung tissue no specific antibody has been detected. Which antigen, then, should we use-the CDC antigen from the New World or indigenously produced antigen from the Old World? And how do we identify a "true case of legionnaires' disease?

We do not yet know how the disease is spread; transmission by airconditioning systems, watercourses, dust (American suggestions), and sheep or insect vectors (to explain the Benidorm hotel cases), and very rarely case-to-case spread, have all been postulated. It is not even clear whether legionnaires' disease is a single entity: it could be a group of diseases caused by a group of similar organisms. Or the legionnaires' disease organism may have altered virulence and different clinical effects in Britain, just as the Treponema pallidum produces two diseases with different virulence: yaws and syphilis. Is the New World giving the Old World another infection or is it endemic in both?

${ }^{1}$ Fraser, D W, et al, New England fournal of Medicine, 1977, 297, 1189.

2 McDade, J E, et al, New England fournal of Medicine, 1977, 297, 1197.

${ }^{3}$ Chandler, F W, Hicklin, M D, and Blackmon, J A, New England fournal of Medicine, 1977, 297, 1218.

${ }^{4}$ Glick, T H, et al, American fournal of Epidemiology, 1978, 107, 149.

${ }^{5}$ Kirby, B D, et al, Annals of Internal Medicine, 1978, 89 (3), 297.

6. Ashford, R F U, Edmonds, M E, and Shanson, D C, Lancet, 1977, 2, 1364.

${ }^{7}$ Macrae, A D, and Lewis, M J, Lancet, 1977, 2, 1225.

"Macrae, A D, British Medical fournal, 1978, 1, 176.

${ }^{9}$ Lawson, J H, Scottish Medical fournal, 1978, 23, 121

"Boyd, J F, et al, fournal of Clinical Pathology, 1978, 31, 809.

\section{Extending the role of the clinical nurse}

As the practice of medicine has become more complex and more demanding with new methods of investigation, new drugs, and new techniques patients' expectations have risen. Understandably, doctors have looked with increasing urgency at those aspects of their work that might, without detriment to their patients, be offered to professional colleagues and particularly to specially trained nurses. But there is nothing obvious or straightforward about nurses accepting responsibility for tasks traditionally performed by doctors: the nurse's basic training fits her to care for people rather than to make diagnoses or initiate treatment. Any extension of her clinical functions could have important legal as well as training implications.
A recent circular ${ }^{1}$ to area health authorities emphasised that a nurse should be specifically and adequately trained for any new task and the doctor who delegates the task should assure himself of the nurse's competence. A doctor might be held to be guilty of negligent delegation were he to authorise a nurse to perform a task which was outside the scope of her normal duties or for which she had no special training; and the nurse, in accepting the task, would be vulnerable at law should anything go wrong.

In practice, nurses have been given responsibility for techniques such as suturing minor wounds; topping up epidural anaesthetics; removing foreign bodies from eyes, ears, and noses; taking cervical smears; inserting intrauterine contraceptive devices; performing outlet forceps deliveries; and repairing episiotomies. Health authorities (and individual doctors) vary in the extent to which they are prepared to delegate these tasks to nurses; and nurses vary in their ability and willingness to accept extra clinical responsibilities. A national training programme to suit all needs would probably be impossible to organise, and the Joint Board of Clinical Nursing Studies ${ }^{2}$ has urged that training in specific procedures should be arranged locally.

More contentious is the substitution of the nurse for the doctor in the primary consultation (the use of the nurse in follow-up consultations, where responsibility can more easily be controlled, is another matter). Moore et $a l^{3}$ had a hospital staff nurse accompany a member of their group practice on 111 new house calls. The nurses' and doctors' decisions on the urgency of the cases were compared, and the results suggested that without additional training the nurse cannot deal safely with primary consultation. When the nurse is specially trained-as in studies reported by Smith and O'Donovan ${ }^{4}$ from the English midlands, by Spitzer $e t a l^{5}$ from a suburban practice in Ontario, and by Wagstaff and Beukes $^{6}$ in the African township of Soweto-it seems that she can offer limited primary health care. In the British report the nurses made about one-third of all the domiciliary visits; they saw patients with infectious diseases, attended to dressings, and did some screening tests. In Ontario they could look after about half the number of patients cared for by doctors, and they referred one-third of these for a medical opinion. Again, what the nurses tackled they did well and to the satisfaction of their patients. In Soweto, bereft of doctors since the 1976 riots, the primary care needs of the African township are now taken care of by specially trained black nurses working closely with the nearby Baragwanath Hospital.

How far the clinical nurse will help in primary care in Britain in the next decade is a matter for doctors, nurses, and patients to judge. Spence ${ }^{7}$ has argued that many lay people have only a faint idea of what the real work of a doctor entails. It is not simply a matter of diagnostic tests, operating theatres, or laboratories. Techniques have their place in medicine, but the essential feature of medical practice is that someone who is ill, or thinks he is ill, seeks the advice of a doctor whom he trusts. All else in the practice of medicine derives from this consultation, and any discussion about extending the role of the clinical nurse must recognise this central fact.

${ }^{1}$ DHSS, The Extending Role of the Clinical Nurse. Legal Implications and Training Requirements, HC(77)22. London, DHSS, 1977.

Joint Board of Clinical Nursing Studies, Bulletin No 18, May 1978.

${ }^{3}$ Moore, M F, et al, Lancet, 1973, 1, 817.

' Smith, J W, and O'Donovan, J B, British Medical fournal, 1970, 4, 673.

Spitzer, W O, et al, New England fournal of Medicine, 1974, 290, 251.

"Wagstaff, L A, and Beukes, P J, South African Medical fournal, 1977, $\mathbf{5 2}, 1086$.

'Spence, J C, The Training and Function of Doctors and Nurses. I ondon, National Association for Mental Health, 1949. 